\title{
FACTORS INFLUENCING WILLINGNESS TO CONTRIBUTE IN CASH WAQF: CASE OF SOUTH TANGERANG, INDONESIA
}

\author{
Hudzaifah Ahmad \\ International Islamic University of Malaysia, Malaysia \\ Email: hudzaifahahmad96@gmail.com
}

\begin{abstract}
Factors Influencing Willingness to Contribute in Cash Waqf: Case of South Tangerang, Indonesia. Waqf has long been the backbone of community service in Indonesia, especially in the fields of religion and education. Considering the importance of waqf in the socio-economic field in Indonesia, the government expanded the scope of waqf which was originally only in the form of fixed assets and then added with movable assets such as money. As a country with the largest Muslim population in the world, Indonesia has a huge cash waqf potential. But this potential has not been able to be optimized by the government or the private sector. The problem of the lack of awareness of Muslims in Indonesia about cash waqf is the main obstacle. There are several factors that influence one's willingness to do cash waqf, namely knowledge, income, social culture, and promotion. To determine the influence of these factors, the data obtained from respondents from the survey instrument adopted were subjected to descriptive analysis statistical analysis. The findings indicate that all factors significantly affect a person's willingness to do cash waqf. Recommendations contingent on research findings were offered.
\end{abstract}

Keywords: Waqf, Cash Waqf, Willingness, Income, Social Culture, Promotion

Abstrak. Faktor-Faktor yang Mempengaruhi Kesediaan untuk Berkontribusi dalam Wakaf Tunai: Kasus Tangerang Selatan, Indonesia. Wakaf telah lama menjadi tulang punggung pengabdian masyarakat di Indonesia, khususnya di bidang agama dan pendidikan. Mengingat pentingnya wakaf dalam bidang sosial ekonomi di Indonesia, pemerintah kemudian memperluas cakupan wakaf yang semula hanya berupa aset tetap menjadi ditambah dengan aset bergerak seperti uang. Sebagai negara dengan populasi Muslim terbesar di dunia, Indonesia memiliki potensi wakaf tunai yang besar. Tetapi potensi ini belum dapat dioptimalkan oleh pemerintah atau sektor swasta. Masalah kurangnya kesadaran umat Islam di Indonesia tentang wakaf tunai adalah kendala utama. Ada beberapa faktor yang mempengaruhi kemauan seseorang untuk melakukan wakaf tunai, yaitu pengetahuan, pendapatan, sosial budaya, dan promosi. Untuk menentukan pengaruh faktor-faktor ini, data yang diperoleh dari responden dari instrumen survei yang diadopsi menjadi sasaran analisis deskriptif analisis statistik. Temuan menunjukkan bahwa semua faktor secara signifikan mempengaruhi kesediaan seseorang untuk melakukan wakaf tunai. Rekomendasi yang bergantung pada temuan penelitian ditawarkan.

Kata Kunci: Wakaf, Wakaf Tunai, Kemauan, Pendapatan, Sosial Budaya, Promosi. 


\section{INTRODUCTION}

As the country with the largest Muslim population in the world, Indonesia also has a problem with very striking poverty and social inequality (Dakwatuna 2016). About 81 percent of the Indonesians are categorized in the bottom of the economic pyramid (BPS, 2015). This leads to a very severe social quality and can slow the rate of economic growth and increase social conflicts. To change this situation, the role of all parties is needed to work together and move sustainably. There are three elements that can significantly impact and mean significant changes from this situation, namely government, religion and society. Endowments with all their uniqueness can represent these three elements simultaneously. First, this is a religious instrument and has often been used for many religious activities. Second, the government can provide regulations that are appropriate to the situation so that it can be accepted by the community. Finally, the waqf comes from the community and to the community. So that all elements that have a significant impact on poverty reduction are all represented and can play their respective roles.

Waqf has become part of Indonesian culture even before Islam entered the Nusantara. Even with different forms and names, endowments are already known by indigenous people. After the entry of Islam into the territory of Indonesia, the waqf has strengthened and garnered. So that at the peak the law No. 41 of 2004 was issued, so that the waqf had legal powers recognized by the state.

The potential of cash in Indonesia is enormous (Hardanawati \& Mughnisari, 2006). According to Nasition (2005), if 10 million Muslim populations in Indonesia are earning an average monthly amount of IDR 5.000.000 (US\$ 370.37) - IDR 10.000.000 (US\$ 740.74) allocated their income to cash waqf institution as much as IDR 100.000 per month, then can be collected fund of about IDR 250 billion per month or equal IDR 3 trillion per year (US\$ 212.8 million). However, according to the Indonesian Waqf Board (or Badan Waqf Indonesia - BWI), the amount of cash waqf collection in Indonesia as per 2013 is just IDR 459 billion (US\$ 34 million) or around $15 \%$ from what has been estimated by Nasution (2005). It can be concluded that the potential of cash waqf in Indonesia has not been optimized properly, and people's willingness of it greatly affects the development of cash waqf. 
Elis Nurhasanah: Feasibility Study Program...

The main objective of this study is to evaluate empirically the level of willingness to pay cash waqf among Muslims in South Tangerang, Indonesia. In this case, efforts were made to answer the following research questions: what is the level of cash waqf in Indonesia at this time? What are the problems faced by cash waqf in Indonesia today? What are the challenges facing cash waqf currently? How does knowledge, income, social culture and promotion have an impact on willingness to do endowments?

The remaining part of this paper is organized as follows. Section 2 presents a brief literature review and hypothesis development. Section 3 provides a brief description of the research method, while section 4 presents empirical findings. Finally, section 5 provides a summary of the study, identifies boundaries, and suggested fields for further research.

\section{WAQF: A REVIEW OF CONCEPT AND ITS POTENTIALS IN INDONESIA}

Waqf according to Arabic means "al-habsu", which comes from the verb habasayahbisu-habsan, which means to keep someone away from something or imprison. Then this word evolves into "habbasa" which means give the treasure for Allah (Adijani, 2004). Literally waqf means "restriction" or "prohibition". Thus, the word waqf (singular: awqaf) is used in Islam for the purpose of "possession and maintenance" of certain property for certain social uses established for the purpose of preventing the use of such waqf property beyond a specific purpose established earlier (Wadjdy, 2007).

According to the Maliki school of thought, waqf does not give up the wealth derived from the ownership of waqif (the one who gives the waqf), but waqf prevents waqif from engaging in actions which can relinquish its ownership of the property to others and waqif is obliged to simplify its benefits and not to return to retrieve its waqf's property (Direktorat Pemberdayaan Wakaf, 2014). Furthermore, Imam Abu Hanifa says that waqf is "the detention of a specific property from the owner's wealth and dedicating its revenue to charitable purpose". The Maliki scholar argues that waqf is "confinement for the cause of God." The Sayfi'i and Hanbali schools define Waqf as "the confinement of one's property and the pledge are its usufruct in perpetuity for the cause of Allah (Mohammed, 2017). 
According to Monzer (2006), waqf in Islamic times has begun simultaneously with the commencement of the prophetic period of Muhammad in Medina marked by the construction of the Quba Mosque, which is a mosque built on the basis of piety from the first, in order to become the first waqf in Islam for the sake of religion. The management of waqf properties has developed very rapidly during the reign of Harun Ar-Rashid (786-809). Waqf properties become more and more widespread, even the purpose of waqf becomes widespread as the Muslim community grows in different directions. Creativity in the development of Islamic endowments is not limited to the existing waqf in general but grows rapidly along with the emergence of the type of waqf and its purpose, moreover in the development of technical problems related to the jurisprudence laws. Understanding about waqf gradually developed and has included several objects, such as land and plantations whose results are used for the benefit of places of worship and religious activities and given to the poor (Wahyuningsih, 2014).

The first person who inaugurated the land belonging to the State (baitulmal) to the foundation and social is King Nuruddin Asy-Syahid with the assertiveness of a fatwa issued by a scholar at that time was Ibn "Ishrun and supported by other scholars that inaugurated property of the state law "can be" (jawaz), with the argument of maintaining and preserving the State's wealth. Because the property that belongs to the State basically should not be represented. Salahuddin Al-Ayyubi many donated state-owned land for educational activities, such as donating some villages (qaryah) for the development of madrassas of the schools of Asy-Syafi'iyah, madrasah al-Malikiyah, and madrasah of al-Hanafiyah schools with funds through the model of donating gardens and agricultural land, such as the construction of the As-Syafi'iyah school beside the grave of Imam Syafi'I by way of donating agricultural gardens and al-Fil islands.

The development of waqf in Indonesia can be said in line with the spread of Islam. In the early days of Islamic broadcasting, the need for mosques to carry out ritual and da'wah activities had a positive impact, namely the provision of waqf land to establish a mosque became a common and widespread tradition in the Islamic communities in Indonesia. Waqf for mosques, educational institutions, pesantren, and cemeteries are the kind of waqf that is best known by the people. This waqf practice 184 
Elis Nurhasanah: Feasibility Study Program...

is assumed to have existed since Islam became a socio-political force with the establishment of several Islamic kingdoms in the Nusantara since the end of the 12th century AD. In East Java, traditions resembling waqf practices have existed since the 15th century $\mathrm{AD}$ and are actually called waqf with the discovery of new historical evidence existed at the beginning of the 16th century (Rahmat, 1982). In Aceh, endowments are mentioned beginning to appear in the 14th century AD (Gazalba, 1989). It should be emphasized, however, that waqf-like practices are reported to have existed long before the arrival of Islam into the Nusantara.

\section{Potentials of Waqf in Indonesia}

There are several factors that are expected to raise optimism about the potential of waqf in Indonesia, namely: first, Indonesia already has institutional legal capital for the development and management of waqf, namely the legal of waqf and its management institutions, as contained in the Waqf Law and its derivative regulations; second, the natural resources and human resources are very large; and thirdly, the income of the Muslim community, especially the upper middle class, which tends to increase (Nizar, 2018). Waqf itself divided into two major categories namely; immovable waqf and movable waqf. Immovable waqf is another name for fix asset endowment, usually consist of land and building. On the other hand, movable waqf is money, cash or something that have high liquidity.

According to Muhammad Afdi Nizar (2017), the potential of cash waqf can be calculated using the following assumptions:

1. Using BPS 2014 data, the number of Indonesian Muslim population is calculated by province. From the calculations obtained estimates the number of Muslim Indonesian population reached 197 million people and spread across 33 provinces.

2. The income level of the population, which is proportioned by the amount of expenditure (consumption), is divided into two groups, namely middle income and high income, which serve as the basis for calculating cash waqf.

3. The calculation of the potential of cash waqf is distinguished by using three scenarios, namely: (I) low (assuming: the waqif population is only 10 per cent of the Muslim population with waqf IDR10,000 per person per month) and (II) 
moderate (assumption: waqif only 25 percent of Muslim population with waqf IDR10,000 per person per month), and (III) optimistic (wakif only 50 percent of Muslim population with waqf IDR10,000 per person per month).

Based on the calculations made by using these assumptions it is known that the potential of money waqf that can be collected from the Indonesian Muslim community is quite large. From the calculations for the three scenarios, it is known that about 98.89 percent of the potential of cash waqf comes from middle-income Muslim population and the rest (1.11\%) is a high-income Muslim waqf potential (Nazir, 2017). If as many as $10 \%, 25 \%$ and $50 \%$ of the population of 194 million Muslims with high income contributed as much as IDR 10,000 per month, the cash waqf proceeds will be collected as much as IDR 2.36 trillion, IDR 5.91 trillion and IDR 11.81 trillion respectively per year explained Nazir (2017). Table 2.1 shows the calculation of cash waqf according to Muslim community income groups in Indonesia.

\section{Potential of Cash Waqf in South Tangerang}

As the youngest city in Banten province, South Tangerang which directly borders with the capital city of Jakarta, which 75.2 percent of its civil servants have education from undergraduate to PhD (BPS, 2016). South Tangerang has a population of 1.5 million people and 75.17 percent of the population is a fixed-income workforce (BPS, 2016). Also, the opportunity to find employment in this area reaches 93.87 percent and is concentrated in three sectors of employment: agriculture, industry and services (BPS, 2016). Moreover, 92.2 percent of the population are Muslims (BPS, 2016) so this makes South Tangerang city has a large potential of cash waqf. Waqf land located in Tangerang area according to Nawawi (head of the minister of religion for Tangerang regional) in 2015 as many as 2,503 locations where all these assets cannot yet be optimized for the benefit of the ummah.

Therefore, the majority of the population of South Tangerang belongs to the middle economic class (BPS, 2015). On the other hand, the potential of cash waqf in South Tangerang cannot be excavated optimally, because the lack of research on cash waqf in the area. In fact, the potential of cash waqf in South Tangerang is big and ready to be optimized even better, but the direct participation of the community as 
Elis Nurhasanah: Feasibility Study Program...

the main character in waqf is very important in this case. The community's willingness to participate in cash waqf is influenced by factors, including; a person's knowledge of the cash waqf itself, the income of a person who influences his readiness to do cash waqf, social culture in the neighborhood also gives a great influence on someone to participate into cash waqf, the last factor is the promotion done by the waqf institution to make the cash waqf known to the public.

\section{EMPIRICAL REVIEW OF AWARENESS ON CASH WAQF}

\section{Study on Willingness of Cash Waqf}

Willingness is the readiness of a person to carry out an action based on the basis of willingness and willingness from within themselves which is influenced by external factors (Slameto, 2010), (Bouckenooghe and Van Den Broeck, 2009), (Asselin, 2005), (Auger et al., 2003), (Nelson and McLeod, 2005).

As stated in the previous chapter, willingness is influenced by various external and internal factors. External factors in the form of information obtained by a person and the wages generated by that person. The family and the surrounding environment are also external factors that can affect a person's willingness to do cash waqf. The most common internal factor in everyone is one's insight into the object. The more a person has insight into an object, the more aware he will be, and vice versa. In this study, there are four factors that can affect someone's willingness to do cash waqf, namely; knowledge, income, social culture, promotion by waqf institution.

\section{Knowledge on Cash Waqf}

The knowledge circulating in Indonesian society about waqf is traditional knowledge, where many still assume that waqf can only be done by using fixed assets. This paradigm that causes the understanding of the community itself only about the management of waqf which is still conventional has not led to a productive direction (Sururdin, 2010). Like the research done by Puad et al. (2014) and Faiz (2014) who reported that lack of knowledge about waqf has caused such lack of awareness about it.

Furthermore, there are still many Muslims in Indonesia who do not understand waqf (Nizar, 2017). This is because Muslims are aware about cash waqf as a matter of 
religious rites, they may not understand its operational mechanism (Adewale et al., 2016). In addition, research conducted by Pikkarainen et al. (2004) states that the amount of information is the most influential factor on the acceptance of a service. Moreover, information has a very important role to acceptance among customers in Pakistan about online bank services (Qureshi, Zafar, \& Khan, 2008). It can be said, when people have basic information about a thing, it will increase their willingness to participate.

\section{Income on Cash Waqf}

Based on research conducted by Iskandar (2017), Mariati (2014), and Danil (2013) states that the income level of a person greatly affects the level of expenditure someone. The income that a Muslim earns is a major source of cash waqf, so a person's income level affects the amount of money he provides for cash waqf. According Nizar (2017) average people who contribute to cash waqf in Indonesia are those who are at the upper middle economic level. This happens because the population of Indonesia to date mostly located at the upper middle economic level, in addition people with low economic levels do not have the ability to contribute in cash waqf.

According to Muttaqin (2015) in his study stated that the income was positive for a person's infaq amount. The greater the income a person, the greater the infaq issued by that person. Moreover, a journal entitled Al-Muzara'ah (2013) states that income variables have a positive influence on the size of the allocation of household infaq.

\section{Social Culture on Cash Waqf}

Norma is one of the factors that contribute to the acceptance of waqf in young intellectuals (Faiz, 2014). Subjective norms can be defined as the perceived effects of social pressure in shaping behavior (Ajzen, 1991). In other words that the norm or behavior of a person in taking a decision is strongly influenced by the environment in which the person lives.

According to Thong (2013) suggest that social culture has a significant impact on the awareness of microfinance program in Selangor. Furthermore, there is a 188 
Elis Nurhasanah: Feasibility Study Program...

positive and statistically significant relationship of social influence on the individual's decision to contribute to charity (Carman, 2004).

Ekawaty dan Muda (2016) in their research states that there are two factors that are very influential in taking a decision that is internal and external factors. Internal factors are the feelings, attitudes, personality and desires of a person. While external factors are family background, social background, culture, information obtained and needs around. Research using statistical descriptions, Z test and multiple regression analysis to test the premier data found out that the knowledge of the people of Surabaya on the money waqf is still low. This is due to internal and external factors which both factors have a significant effect on the outcome.

\section{Promotion on Cash Waqf}

There are allegations that the lack of promotion by money waqf institutions in Indonesia has led to a low level of willingness of the community to contribute to it. The above is supported by statements issued by BWI (2010), the socialization of money waqf to the general public is very necessary to see at least the funds raised waqf. Then the research conducted by Ibrahim et al (2013) stating that the lack of promotion about the contribution and practice of Waqf each may have major implications for the willingness needed to exploit the socio-economic potential of cash waqf as an Islamic social finance option.

As said by Jati (2017), there is a positive and significant relationship between online marketing strategies and consumer buying interest. In addition, Thong et al. (2013) in their research have found that the use of marketing and promotional tools has raised awareness about microfinance among people in the central region of Malaysia. According to Aziz (2015) the mass media has the ability to multiply such amazing messages so that what is delivered (promoted) in the mass media will have a tremendous impact on society. This can make it easier for waqf institutions to form a good public opinion about cash waqf, which has been underestimated by the vast majority of the population in Indonesia. 


\section{METHODOLOGY}

\section{Conceptual Framework}

The conceptual framework is a relationship or relationship between one concept and another concept of the problem to be studied. This conceptual framework is used to connect or explain structurally about a topic to be discussed. This framework is derived from the concept of science / theory that is used as the basis of research obtained from the literature review chapter.

The conceptual framework is expected to be able to illustrate and direct assumptions about the variables that will be examined. The conceptual framework provides guidance to researchers in formulating research problems. The conceptual framework is composed of independent and dependent variables (Table 1).

Table 1. Conceptual Framework

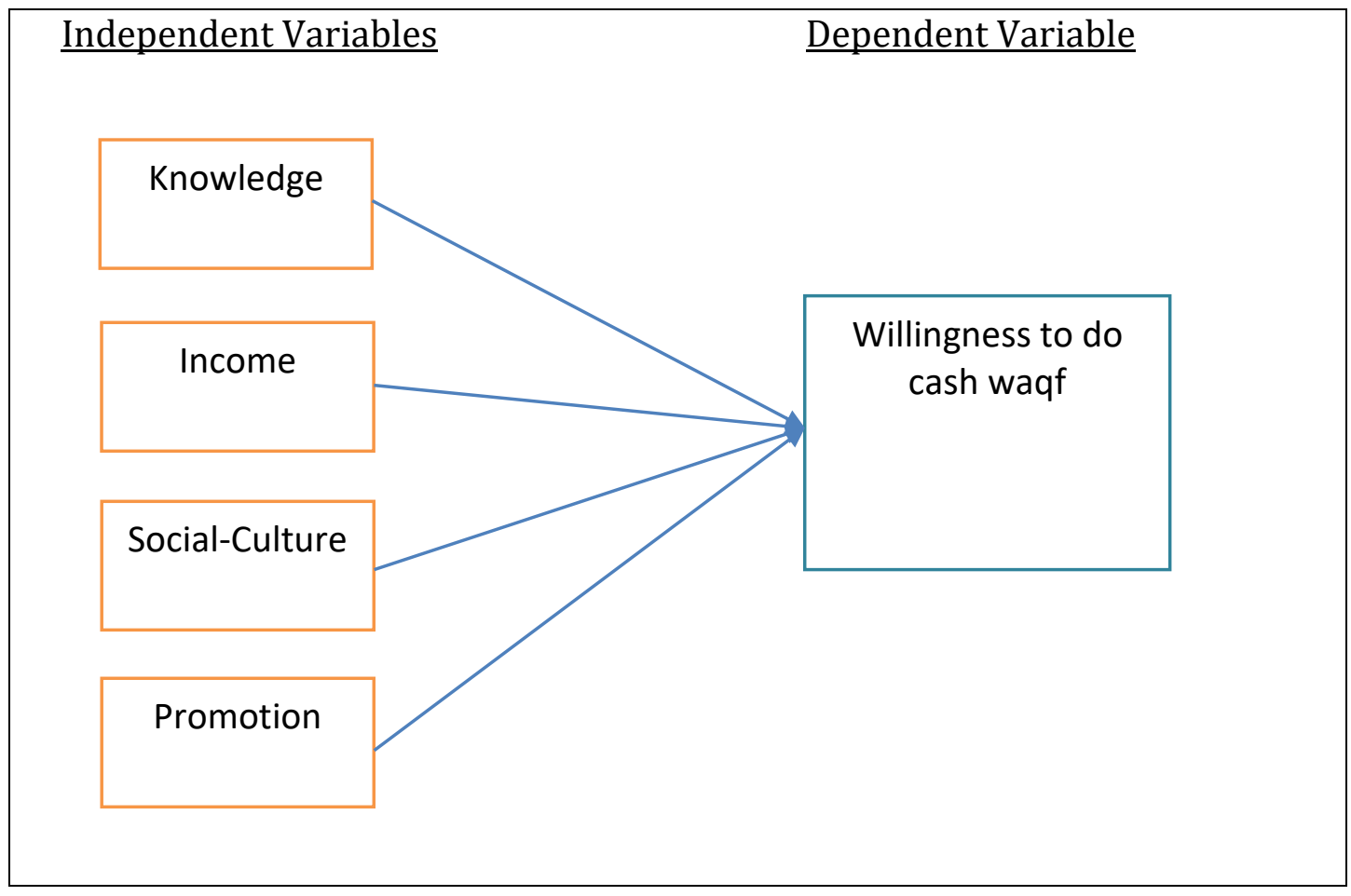

At the diagram above, it can be seen that there are four independent variables and one dependent variable. The independent variables in this study are knowledge, income, culture and promotion. While the dependent variable in this research is 
Elis Nurhasanah: Feasibility Study Program...

willingness to perform cash waqf. Any relationship between the independent variable and the dependent variable will form a hypothesis.

\section{Hypotheses Development}

In order to determine whether a hypothesis is accepted or rejected it is necessary to test the hypothesis, i.e. through statistical $\mathrm{F}$ test and statistical $\mathrm{t}$ test or from the significance generated by the test. First determined the level of significance of $95 \%$ or error rate of $5 \%$ and pay attention to the number of observations. Based on the above then made a comparison between $\mathrm{t}$ arithmetic with $\mathrm{t}$-table or see Probability of the processing generated by the program statistical data.

Ha1: Knowledge has an influence on willingness to do cash waqf.

Ho1: Knowledge has no influence on willingness to do cash waqf.

Ha2: Income has an influence on willingness to do cash waqf.

Ho2: Income has no influence on willingness to do cash waqf.

Ha3: Social-culture has an influence on willingness to do cash waqf.

Ho3: Social-culture has no influence on willingness to do cash waqf.

Ha4: Promotion has an influence on willingness to do cash waqf.

Ho4: Promotion has no influence on willingness to do cash waqf.

\section{Data}

In the process, data is the main input that will produce output to answer problems and research questions. In general, there are two types of data that are generally used to conduct research, namely primary and secondary data. This study uses a questionnaire to obtain primary data. Questionnaires were distributed randomly in the South Tangerang area. Thus, determining the number of samples follows Sholihin and Ratmono (2013). There are 1.1 million people in South Tangerang in 2017, 200 samples are needed. Distributed to respondents who have income and above 20 years. Instruments given to respondents by face to face and 
electronically. There were 34 questions in the questionnaire submitted by the respondent. This instrument is based on a five-point Likert scale that ranges from 1strongly disagree to 5 - strongly agree

\section{Demographic Profile and Respondents}

Out of 400 distributed surveys, 386 were duly completed representing a response rate of 96.5 percent. Four of the surveys were obtained through Facebook, four from emails, and the remaining 378 from direct face to face method.

As indicated in Table 1 below, the distribution of respondents seems suitable for the present study. Although most of the respondents are females, the males are also represented by a sizeable number. While most are in their early adult life, almost half have at least a university degree and work in the private sector. This may imply that they are likely to be very clear about what the items in the questionnaire sought to elicit from them. Moreover, being economically active based on age groupings makes most respondents eligible to participate in Cash Waqf activity, especially as potential donors. Less than a third of the respondents earn less than IDR 1,000,000 monthly. It is envisaged that this demographic distribution would have positive implication for the quality of the data elicited in this study. As such meaningful inferences could be drawn therefrom.

Table 2. Respondent's Profile

\begin{tabular}{|lcrr|}
\hline Factor & Total (N) & Frequency & Percentages \\
\hline $\begin{array}{l}\text { Gender } \\
\text { Female }\end{array}$ & 386 & 241 & 62.4 \\
\hline $\begin{array}{l}\text { Age } \\
20-30 \text { years }\end{array}$ & 386 & 226 & 58.5 \\
\hline $\begin{array}{l}\text { Occupation } \\
\text { Private Servant }\end{array}$ & 386 & 186 & 48.2 \\
\hline $\begin{array}{l}\text { Income Level } \\
\text { <IDR 1.000.000 }\end{array}$ & 386 & 115 & 29.8 \\
\hline $\begin{array}{l}\text { Education } \\
\text { Bachelor Degree }\end{array}$ & 386 & 160 & 41.5 \\
\hline
\end{tabular}




\section{Result}

In order to provide the right answers to the questions from this study, respondents were given questions related to their understanding with cash waqf. Then questions related to other factors such as income, social culture and promotion were also given to respondents. Questions about the willingness of the respondent to do cash waqf are also given. The results obtained from the Likert scale are statistically significant. The results of the probity regression analysis show that the knowledge, income, socio-cultural and promotion of the simultaneous test results obtained a significant probability level of $0.000 \leq 0.05$. Thus, it can be concluded that the regression model can be used together with independent variables affect the dependent variable and there is at least one variable that significantly affects the interest of the community in representing money. For test $z$, it can be concluded that knowledge and income have a significant effect on the willingness of the community to carry out cash waqf. Whereas socio-culture and promotion have no significant effect on the willingness of the community to carry out cash waqf.

A multiple linear regression analysis was carried out in order to examine the variance in awareness about Cash Waqf (Aw) scores. The Enter method was used to load three predictors into the model. The results obtained indicated that model was able to explain $63 \%$ of the sample outcome variance (Adj. $R=62.7 \%$ ). This was found to significantly predict outcome, $\mathrm{F}(3,382)=216.957, \mathrm{p}<.001$. The three predictor variables significantly contributed to the model. The most significant factor found is the 'knowledge' factor with $(\mathrm{B}=0.632, \mathrm{t}=12.832$ and sig $<0.001)$, followed by the 'promotion' factor with $(\mathrm{B}=0.172, \mathrm{t}=3.562$ and $\mathrm{p}<0.001)$ and followed by the 'Income' factor with ( $\mathrm{B}=0.166, \mathrm{t}=3.554$ and $\mathrm{p}<0.001$ ), last but not least the 'social culture' factor with $(B=0.160, t=3.551$ and $p<0.001)$. The results are shown in table 3 below.

Table 3. Summary of Regression Analysis Results

\begin{tabular}{|l|lllllll|}
\hline $\begin{array}{l}\text { Predictor } \\
\text { Variable }\end{array}$ & R2 & Adj.R2 & $F$ & $p$ & Gradient & p & p \\
\hline & & & & & & &
\end{tabular}


Islamiconomic: Jurnal Ekonomi Islam Vol.10 No.2 Juli - Desember 2019

\begin{tabular}{|c|c|c|c|c|c|}
\hline Model & 0.63 & $0.627 \quad 216.96$ & $<0.001$ & & \\
\hline Knowledge & & & 0.632 & 12.832 & $<0.001$ \\
\hline Income & & & 0.166 & 3.554 & $<0.001$ \\
\hline Social-Culture & & & 0.160 & 3.551 & $<0.001$ \\
\hline Promotion & & & 0.172 & 3.562 & $<0.001$ \\
\hline
\end{tabular}

The current state of willingness to do cash waqf of the people of South Tangerang is high, this denies the research conducted by Puad et al. (2014), Ibrahim, et.al. (2013), Osman, et.al. (2012), Marzuki, et.al. (2012), Nurrachimi, et.al. (2012), Mohsin (2009), Mahmood (2007) and others that the willingness of cash Waqf among Indonesian Muslims is still low.

\section{CONCLUSION}

The conclusion that in this study provides empirical evidence that one's willingness is significantly influenced by factors such as knowledge, income, social culture and promotion. In addition, the level of public willingness in South Tangerang to carry out cash waqf is already high, but the instruments to do it are still not optimal so that the potential of cash waqf in Indonesia is still not able to be utilized optimally. The implication of these findings is the management of endowments of fixed assets to be productive and can be used for the good of the people.

\section{REFERENCES}

Republika.co.id. (2009, 02 05). Retrieved from Republika Web site:

https://www.republika.co.id/berita//no-channel/09/02/05/29875-sejarahdan-perkembangan-wakaf

Adewale, A. A., Ismail , N. A., \& Sabariah, B. S. (2016). An Empirical Investigation of the Determinants of Cash Waqf Awareness in Malaysia. IIUM Journal, 505.

Adijani, a.-A. (2004). Perwakafan tanah di Indonesia. Jakarta: PT. Raja Grafindo Persada.

Ahmed, H. (2007). Waqf-based microfinance: realizing the social role of Islamic finance. Integrating Awqaf, -.

Ali, M. D. (1988). Sistem Ekonomi Islam, Zakat dan Wakaf. UI Press, 78. 
Elis Nurhasanah: Feasibility Study Program...

Al-Mughny. (1997). Al-Mughni. In I. Qudamah, Al-Mughni (pp. -). -: -.

Al-Muzara'ah. (2018, February 20). Pengaruh Level Pendapatan Terhadap Level Konsumsi Rumah Tangga. Journal of Islamic Economics and Finance, p. 1.

Amin, H., Abdul Rahman, A. R., Ramayah, T., Supinah , R., \& Mohd , A. M. (2014).

Determinants of Online Waqf Aceptance : An Empirical Investigation . EJISDC (8), 1-18.

Arif, S. (2010). Wakaf tunai sebagai alternatif mekanisme redistribusi keuangan islam. La_Riba, Jurnal Ekonomis Islam.

Arifin, J. (2014). Problematika Perwakafan di Indonesia. ZISWAF, 263.

Ash Shiddieqy, H. T. (2001). Hukum-Hukum Fiqh Islam. Semarang : PT. Pustaka Rizki Putra.

Atabik, A. (2014). Strategi Pendayagunaan dan Pegelolaan Wakaf Tunai di Indonesia. Ziswaf, 315.

Aziz. (2015, March 22). Index: Wordpress. Retrieved from Wordpress web site:

https://azizuncen09.wordpress.com/2015/03/22/pengaruh-media-massa-

terhadap-pembentukan-opini-publik/

BPS. (2015). Susenas 2014. Jakarta: Badan Pusat Statistik.

BPS. (2017). Agustus 2017: Tingkat Pengangguran Terbuka (TPT) sebesar 5,50 persen.

Jakarta: BPS (Badan Pusat Statistik.

BPS. (2017). Garis Kemiskinan Menurut Provinsi, 2013 - 2017. Jakarta: BPS (Badan Pusat Statistik) .

BPS South Tangerang . (2016). Kota Tangerang Selatan Dalam Angka. Statistik Daerah Kota Tangerang Selatan 2016, 10.

BPS South Tangerang. (2016). Kota Tangerang Selatan Dalam Angka. Statistik Daerah Kota Tangerang Selatan 2016, 6.

BPS South Tangerang. (2016, August -). Kota Tangerang Selatan Dalam Angka. Katalog BPS, p. 49.

BPS South tangerang. (2016). Kota Tangerang Selatan Dalam Angka . Statistik Daerah Kota Tangerang Selatan 2016, 2.

Budiman, A. (2017, September 22). Pikiran-Rakyat.com. Retrieved from BNI Syariah Salurkan Wakaf Uang untuk Pembuatan Film Iqro 2: http://www.pikiran- 
rakyat.com/ekonomi/2017/09/22/bni-syariah-salurkan-wakaf-uang-untukpembuatan-film-iqro-2-410000

BWI. (2010, May 25). BWI: Index. Retrieved from Sosialisasi Wakaf Uang Harus Digenjot: http://bwi.or.id/index.php/en/publikasi/news/633-sosialisasiwakaf-uang-harus-digenjot.html

Carman, K. G. (2004). Social Influences and the Designation of Charitable Contributions: Evidence from the Workplace . Harvard University Journal, 1.

Dakwatuna. (2016, March 05). Optimalisasi Potensi Wakaf Uang Dalam Pembangunan Sumber Daya dan Kesejahteraan Rakyat Kecil. Retrieved from dakwatuna web site: https://www.dakwatuna.com/2016/03/05/79433/optimalisasi-potensiwakaf-uang-pembangunan-sumber-daya-dan-kesejahteraan-rakyatkecil/\#axzz5CGHuPmqX

Damhuri, E. (2017, October 13). Republika.co.id. Retrieved from Quo Vadis Gerakan Wakaf Uang: http://www.republika.co.id/berita/jurnalismewarga/wacana/17/10/13/oxqkg2440-quo-vadis-gerakan-wakaf-uang

Danil, M. (2013). PENGARUH PENDAPATAN TERHADAP TINGKAT KONSUMSIPADA PEGAWAI NEGERI SIPIL DI KANTOR BUPATIKABUPATEN BIREUEN. Jurnal ekonomika Universitas Almuslim Bireuen, 1.

Direktorat Pemberdayaan Wakaf. (2014). Fikih Wakaf. -: Direktorat Pemberdayaan Wakaf.

Ekawaty, M., \& Muda, A. W. (2016). Wakaf Uang: Tingkat Pemahaman Masyarakat \& Faktor Penentunya (Studi Masyarakat Muslim Kota Surabaya, Indonesia). IQTISHODUNA, 2.

Ekinci, E. B. (2016, JUne 3). The social role of waqfs during the Ottoman era. Retrieved from dailysabah.com:

https://www.dailysabah.com/feature/2016/06/03/the-social-role-of-waqfsduring-the-ottoman-eradailysabah.com

Faiz, O. (2014). An Analysis of Cash Waqf Participation among Young Intellectual. Instanbul: International Academic Conference.

Faizah, S. I., Laila, N., \& Hendratmi , A. (2013). PRODUCTIVE WAQF AS ONE OF THE PROBLEMATIC TO UNEMPLOYMENT IN INDONESIA. ISS \& $M L B, 590$.

Gazalba, S. (1989). Masjid Pusat Ibadah dan Kebuadayaan. Pustaka Al-Husna, 117. 196 
Elis Nurhasanah: Feasibility Study Program...

Hardanawati , L. U., \& Mughnisari, F. (2006). Waqf Experience in Indonesia. Ekonomi dan Keuangan Syariah, Fakultas Pascasarjana, Universitas Indonesia, 1.

Ibrahim, D., \& Ibrahim, H. (2013). Revival of Waqf Properties in Malaysia. Paper Proceeding of the 5th Economics System Conference , 2.

Ikhsanudin, M. (2012). Optimalisasi wakaf produktif bagi lembaga pendidikan dan ormas Islam di Indonesia. Mukaddimah , 18.

Indonesian Waqf Board. (2008). Dabase dan Potensi Wakaf. Jakarta: Badan Wakaf Indonesia .

Isin, E. F. (2011). Ottoman Waqfs as Acts of Citizenships.

Iskandar. (2017, October 2). Pengaruh Pendapatan Terhadap Pola Pengeluaran Rumah Tangga Miskin Di Kota Langsa. JURNAL SAMUDRA EKONOMIKA, p. 1.

Jati, W. (2017). PENGARUH STRATEGI PEMASARAN ONLINE (ONLINEARKETING STRATEGY) TERHADAP MINAT BELI KONSUMEN. Jurnal Pemasaran Kompetitif, 125.

Magda, I. A., Hisham, D., Cizackca, M., Alhabshi, S. O., Razak, S. H., Sadr, S. K., et al. (2016). Financing the Development of Old Waqf Properties. New York: Palgrave Macmillan.

Mano, R. S. (2013). Social Media, social causes, giving behavior and money contribution. Computers in Human Behavior, 287-293.

Mariati. (2014). PENGARUH PENDAPATAN TERHADAP PENGELUARAN RUMAH TANGGA PEKERJA PERKEBUNAN KELAPA SAWIT DI KECAMATAN INDRA MAKMU. Jurnal Fakultas Keguruan dan Ilmu Pendidikan, 1.

Mohammed, A. S. (2017). An Exploratory Study On Awarness of Waqf Among Kenyan Muslims. International Islamic University Malaysia Journal , 16-17.

Mohammed, A. S. (2017). An Explporatory Study on Awareness of Waqf Among Kenyan Muslims. International Islamic University Malaysia Journal, 18.

Muttaqin , Z. (2015). ANALISIS PENGARUH PENDAPATAN TERHADAP JUMLAH INFAQ PESERTA PENGAJIAN ROHANI Studi Kasus Majelis Ta'lim di Masjid Al. Jurnal Ekonomi dan Hukum Islam, 25.

Nizar, M. A. (2017). PENGEMBANGAN WAKAF PRODUKTIF DI INDONESIA : POTENSI DAN PERMASALAHAN. Research Gate, 237. 
Islamiconomic: Jurnal Ekonomi Islam Vol.10 No.2 Juli - Desember 2019

Nizar, M. A. (2017). PENGEMBANGAN WAKAF PRODUKTIF DI INDONESIA : POTENSI DAN PERMASALAHAN. Research Gate, 235.

Nizar, M. A. (2018). PENGEMBANGAN WAKAF PRODUKTIF DI INDONESIA : POTENSI DAN PERMASALAHAN. Research Gate, 233.

Nizar, M. A. (2018). PENGEMBANGAN WAKAF PRODUKTIF DI INDONESIA : POTENSI DAN PERMASALAHAN. Research Gate, 235-236.

Nizar, M. A. (2018). PENGEMBANGAN WAKAF PRODUKTIF DI INDONESIA: POTENSI DAN PERMASALAHAN. Research Gate, 232.

Orbay, K. (2006). The Economic Efficiency of Imperial Waqfs in the Ottoman Empire. XIV International Economic History Congress, -.

Panjimas.com. (2017, December 15). Panjimas.com. Retrieved from BWI: Potensi Wakaf Uang di Indonesia Capai Rp 180 Triliun: http://www.panjimas.com/news/2017/12/15/bwi-potensi-wakaf-uang-diindonesia-capai-rp-180-triliun/

Pikkarainen, T., Karjaluoto, K. H., \& Pahnila S. (2004). Consumer Acceptance of Online Banking: An Extension of the Technology. Acceptance Model, Internet Research,, 224235.

Puad, N., Rafdi, N., \& Shahar, W. (2014). Issue and Challanges of Waqf Instrument . A Case Study In MIAS.

Qahaf, M. (2006). Al-Waqf al-Islami Tatawwuruhu. Idaratuhu, Tanmiyatuhu, 29-30.

Qureshi, T. M., Zafar, M. K., \& Khan, M. B. (2008). Customer Acceptance of Online Banking in Developing Ecinomies. Journal of Internet Banking and Commerce , 20-32.

Rahmat, D. (1982). Wakaf Tanah. Surabaya: Al-Ikhlas, 20-24.

Rasyid, A. (2016). POTENSI WAKAF UANG DI INDONESIA. Binus Journal, 1.

Republika. (2014, January 13). Khazanah. Retrieved from Republika web site: http://republika.co.id/berita/dunia-islam/hikmah/14/01/13/mzbetu-hariini-islam-jadi-agama-terbesar-di-dunia

Republika. (2015, May 27). Khazanah. Retrieved from Republika web site: http://republika.co.id/berita/dunia-islam/islamnusantara/15/05/27/noywh5-inilah-10-negara-dengan-populasi-muslimterbesar-di-dunia 
Elis Nurhasanah: Feasibility Study Program...

Republika. (2017, October 03). Khazanah. Retrieved from Republika web site:

http://khazanah.republika.co.id/berita/dunia-

islam/wakaf/17/10/03/ox90mi396-tanah-wakaf-indonesia-5-kali-lebih-luasdari-singapura

Sembiring , L. J. (2017, August 23). Okezone Finance. Retrieved from Sri Mulyani:

Wakaf Tunai Bisa Capai Triliunan Rupiah!:

https://economy.okezone.com/read/2017/08/23/20/1761333/sri-mulyani-

wakaf-tunai-bisa-capai-triliunan-rupiah

Snipes, R. L., \& Oswald, S. L. (2010). Charitable giving to not-for-profit organization:

Factors affecting donations to non-profit organizations. Innovative Marketing, 1.

Soemarti, A. (2017, March 15). Majelis Ulama Indonesia Kota Medan. Retrieved from Konsepsi Wakaf Uang di Indonesia : http://muimedan.com/2017/03/15/konsepsi-wakaf-uang-di-indonesia/

Sururdin. (2010, August 27). Wordpress. Retrieved from Pelaksanaan Wakaf Uang dan Sosialisasinya: https://sururudin.wordpress.com/2010/08/27/pelaksanaanwakaf-uang-dan-sosialisasinya/

Thong, S. K., Chye, C. S., \& Fong, W. S. (2013). Awarenessof Microfinance Within The Centra Region,Malaysia. International Conference on Management, 3.

Wadjdy, F. (2007). Wakaf \& kesejahteraan umat. Yogyakarta: Pustaka Pelajar.

Wahyuningsih, S. (2014). Implementasi Sistem Pendidikan Islam Pada Masa Daulah Abbasyiah dan Pada Masa Sekarang. Jurnal Kependidikan, 115-120.

Widaningrum, D. I. (2007). Identifikasi kemampuan dan kemauan membayar masyarakat berpenghasilan menengah rendah . http://kk.pl.itb.ac.id/ppk., 1.

World Almanac. (2011). The World Almanac and Book of Facts 2011. New York: Newgen North America. 
Islamiconomic: Jurnal Ekonomi Islam Vol.10 No.2 Juli - Desember 2019 